J. Dairy Sci. 101:5145-5152

https://doi.org/10.3168/jds.2017-13880

(ㄷ 2018, THE AUTHORS. Published by FASS Inc. and Elsevier Inc. on behalf of the American Dairy Science Association ${ }^{\circledR}$.

This is an open access article under the CC BY-NC-ND license (http://creativecommons.org/licenses/by-nc-nd/3.0/).

\title{
Effects of homolactic bacterial inoculant on the performance of lactating dairy cows
}

\author{
J. L. P. Daniel, ${ }^{\star} \dagger$ O. C. M. Queiroz, ${ }^{*}$ K. G. Arriola, ${ }^{*}$ R. Daetz, ${ }^{*}$ F. Basso, $\ddagger$ J. J. Romero,§ and A. T. Adesogan ${ }^{* 1}$ \\ *Department of Animal Sciences, Institute of Food and Agricultural Sciences, University of Florida, Gainesville 32611 \\ †Department of Animal Science, State University of Maringá, Maringá, Brazil, 87020900 \\ łDepartment of Animal Sciences, The São Paulo State University, Jaboticabal, Brazil, 14884900 \\ $\S$ Animal and Veterinary Sciences Program, School of Food and Agriculture, University of Maine, Orono 04469
}

\section{ABSTRACT}

The objective of this experiment was to determine the effect of applying a homofermentative bacterial inoculant to corn silage on the performance of dairy cows. After harvesting, corn forage was treated with nothing $(\mathrm{CON})$ or with an inoculant containing a mixture of Lactococcus lactis, Lactobacillus plantarum, and Enterococcus faecium at $1.5 \times 10^{5} \mathrm{cfu} / \mathrm{g}$ of fresh forage (MC; SiloSolve MC, Chr. Hansen A/S, Hørsholm, Denmark). After $186 \mathrm{~d}$ of storage in Ag-Bags (A Miller-St. Nazianz Inc., St. Nazianz, WI), silages were fed as part of a total mixed ration containing $55 \%$ concentrates, $10 \%$ alfalfa hay, and $35 \%$ CON or MC corn silage. Sixty early-lactation Holstein dairy cows (30 multiparous and 30 primiparous) housed in a freestall barn with Calan gates (American Calan Inc., Northwood, NH) were assigned to the dietary treatments from 20 to $100 \mathrm{~d}$ in milk. Silage inoculated with MC had a more homofermentative pattern evidenced by greater lactic acid concentration (3.83 vs. $4.48 \%$ of DM) and lower concentrations of acetic (2.34 vs. $1.68 \%$ of $\mathrm{DM})$ and propionic ( 0.37 vs. $0.10 \%$ of $\mathrm{DM}$ ) acids and ammonia (9.11 vs. $7.82 \%$ of $\mathrm{N}$ ) for $\mathrm{CON}$ and $\mathrm{MC}$, respectively. Dry matter intake (23.1 vs. $23.2 \mathrm{~kg} / \mathrm{d}$ ) did not differ among treatments, but the MC silage had greater apparent digestibility of DM (68.8 vs. $70.8 \%$ ), which led to greater yields of milk (37.7 vs. $38.5 \mathrm{~kg} / \mathrm{d})$, fat-corrected milk ( 37.6 vs. $38.4 \mathrm{~kg} / \mathrm{d})$, milk fat (1.30 vs. $1.33 \mathrm{~kg} / \mathrm{d}$ ), and lactose (1.83 vs. $1.92 \mathrm{~kg} / \mathrm{d}$ ) for CON and MC cows, respectively. Milk from cows fed MC silage had higher lactose (4.86 vs. $4.93 \%$ ), lower protein (2.93 vs. $2.83 \%$ ), and similar contents of fat (3.47 vs. $3.44 \%$ ) compared with CON cows. Feed efficiency (fat-corrected milk/ dry matter intake) was not affected by treatment (1.69 vs. 1.72 for $\mathrm{CON}$ and MC, respectively). Inoculation of corn silage with the homofermentative inoculant

Received September 22, 2017

Accepted January 9, 2018

${ }^{1}$ Corresponding author: adesogan@ufl.edu increased digestibility of the total mixed ration and increased milk yield by lactating dairy cows.

Key words: corn silage, homolactic silage inoculant, milk yield

\section{INTRODUCTION}

Lactic acid bacteria (LAB) have been used as inoculants to improve silage fermentation and aerobic stability. Beyond their effects on silage conservation, LAB that survive in the gastrointestinal tract of ruminants may exert probiotic effects (Weinberg et al., 2003; Han et al., 2014) and thereby potentially enhance animal performance (Weinberg et al., 2004).

Although the effects of LAB inoculation on animal performance are not consistent, previous studies have reported beneficial effects of LAB in rumen fluid such as increased microbial biomass yield (Contreras-Govea et al., 2011; Basso et al., 2014) and lower methane production (Muck et al., 2007; Cao et al., 2010). In addition, inoculation of silage with LAB has increased DM digestibility both in vitro (Weinberg et al., 2007; Cao et al., 2011) and in vivo (Kung et al., 2003; Ando et al., 2006). Recently, we conducted a meta-analysis on the effects of homofermentative and facultative heterofermentative LAB on the performance of dairy cows (Oliveira et al., 2017). Silages inoculated with at least $10^{5} \mathrm{cfu}$ of $\mathrm{LAB} / \mathrm{g}$ of fresh forage increased milk yield by $0.37 \mathrm{~kg} / \mathrm{d}$ and tended to increase DMI and milk fat and protein concentrations; therefore, inoculating corn silage with homofermentative LAB may be an effective strategy to improve the performance of lactating dairy cows. However, the meta-analysis showed that most $(67 \%)$ of the studies involved inoculation of silage with only Lactobacillus plantarum and that relatively fewer studies involved other single bacteria or mixtures of LAB. Such mixtures typically include $L b$. plantarum and bacteria such as Enterococcus faecium or Pediococcus pentosaceus. The latter 2 bacteria cause a faster initiation of the $\mathrm{pH}$ decline than $L$ b. plantarum because they are more dominant and effective at fermenting 
plant sugars when the prevailing $\mathrm{pH}$ is above 5 during the early stages of fermentation (McDonald et al., 1991). Consequently, combinations of homofermentative bacteria can result in more efficient fermentations with less DM losses (Lindgren et al., 1985) and potentially improve nutrient intake and utilization. Thus, more research is needed on effects of such combinations of bacteria on milk production by lactating dairy cows.

The objective of this experiment was to determine the effect of applying a homofermentative bacterial inoculant to corn silage on the performance of dairy cows fed the corn silage as part of a TMR. We hypothesized that application of the homofermentative inoculant would improve the performance of dairy cows in early lactation.

\section{MATERIALS AND METHODS}

\section{Silage Production}

Pioneer 31P42 corn hybrid (Dupont Pioneer, Des Moines, IA) was harvested at approximately 35\% DM with a forage harvester (Claas Jaguar 980, Claas of America LLC., Columbus, IN) adjusted to a theoretical length of cut of $19 \mathrm{~mm}$ and a roll clearance of 2 $\mathrm{mm}$. At harvest, fresh chopped forage was sampled and analyzed for major nutrients and LAB counts using the same procedures described below for silage samples. The corn crop contained (DM basis) $8.05 \%$ CP, $43.4 \%$ NDF, 26.0\% ADF, 3.05\% ether extract, 3.26\% ash, $42.2 \% \mathrm{NFC}$, and $6.10 \mathrm{log}$ cfu of LAB/g of fresh forage.

Harvested forage was treated with nothing (CON) or with an inoculant containing a mixture of Lactococcus lactis SR 3.54, Lb. plantarum CH6072, and E. faecium M74 at $1.5 \times 10^{5} \mathrm{cfu} / \mathrm{g}$ of fresh forage (MC; SiloSolve MC, Chr. Hansen A/S, Hørsholm, Denmark). Forage from the respective treatments was packed into 2 replicate 3.66-m-wide Ag-Bags (A Miller-St. Nazianz Inc., St Nazianz, WI) with a Versa 1012 bagger (Versa Corp., Astoria, OR) and stored for $186 \mathrm{~d}$ before the lactation trial. To ensure that similar forage was used for each treatment, the corn field was divided into blocks; the forage from the first windrow in each block was packed into the first replicate control bag, and forage from the second windrow was packed into the first replicate MC bag. Forage from subsequent windrows was successively packed using a similar sequence into the respective bags for each treatment.

\section{Cows and Sampling}

All experimental cows were managed according to the guidelines approved by the University of Florida
Institute of Food and Agricultural Sciences Animal Research Committee. Sixty lactating Holstein cows (30 multiparous and 30 primiparous) were housed in a freestall barn with sand-bedded stalls and randomly assigned at 10 DIM to a feeding gate (Calan Broadbent Feeding System, American Calan Inc., Northwood, $\mathrm{NH})$ to allow measurement of individual feed intake. The experimental pens were equipped with 2 rows of fans (1 fan/6 linear meters), one row facing the feed lane immediately above the feedbunk and the other immediately above the beds. Fans were activated once ambient temperature reached $21.1^{\circ} \mathrm{C}$.

During the pretreatment period (10-20 DIM), cows were fed the same diet containing half of the corn silage from each treatment. At 20 DIM, weekly cohorts were blocked by parity (primiparous and multiparous) and milk yield and, within each block, randomly assigned to 1 of the 2 treatments (CON or MC) and then enrolled in the trial. The cohorts were assigned to the trial from April 2 to September 4, 2012, over the spring and summer months. Experimental diets were compared for 80 d from 20 to 100 DIM. Cows were weighed on 2 consecutive days immediately after the morning milking at the beginning and end of the trial. Average BW was used to calculate the maintenance energy requirement (Mcal/d) as $0.08 \times \mathrm{BW}^{0.75}$ (NRC, 2001).

Diets were formulated to meet the nutrient requirements of dairy cows producing $40 \mathrm{~kg}$ of milk (NRC, 2001). Diets contained 55\% concentrates, $10 \%$ alfalfa hay, and $35 \%$ CON or MC corn silage, fed as a TMR twice daily, at 0800 (after the morning milking) and $1230 \mathrm{~h}$. Refusals were weighed once daily at $0700 \mathrm{~h}$, and the amounts were used to ensure that $105 \%$ of the previous day's feed intake for each cow was offered. Once weekly, individual ingredients and the TMR were sampled, dried at $60^{\circ} \mathrm{C}$, and stored under refrigeration $\left(5^{\circ} \mathrm{C}\right)$ for later analyses as monthly composites. Fresh samples of silages were also frozen $\left(-20^{\circ} \mathrm{C}\right)$ for later analyses of fermentation end products. Aerobic stability tests were performed every month as described by Queiroz et al. (2013). Briefly, $2 \mathrm{~kg}$ of silage was placed in an open-top polystyrene box and exposed to air for 14 d. Aerobic stability was denoted as the length of time that elapsed before silage and ambient temperatures differed by more than $2^{\circ} \mathrm{C}$.

Cows were milked twice daily at 0730 and $1900 \mathrm{~h}$, and individual milk samples were collected once weekly from consecutive morning and afternoon milkings. Samples were analyzed by Southeast Dairy Laboratories (Belleview, FL) for fat, protein, lactose, MUN, and SCC using a Bentley 2000 near-infrared reflectance spectrophotometer (Bentley Instruments Inc., Chaska, $\mathrm{MN})$. Final concentrations of milk components were 
calculated after adjustment for milk production during morning and afternoon milkings. Production of 3.5\% FCM was calculated using the Tyrrell and Reid (1965) equation: FCM $(\mathrm{kg} / \mathrm{d})=0.4324 \times$ milk yield $(\mathrm{kg} / \mathrm{d})$ $+16.216 \times$ milk fat yield $(\mathrm{kg} / \mathrm{d})$. Milk energy content was calculated using the NRC (2001) equation: milk net energy $(\mathrm{Mcal} / \mathrm{kg})=0.0929 \times$ fat $\%+0.0547 \times$ protein $\%+0.0395 \times$ lactose $\%$. Daily secretion of milk energy $(\mathrm{Mcal} / \mathrm{d})$ was computed as milk net energy $\times$ milk yield.

From 70 to 80 DIM, cows were dosed orally twice daily with a gelatin capsule containing $10 \mathrm{~g}$ of $\mathrm{Cr}_{2} \mathrm{O}_{3}$ $(20 \mathrm{~g} / \mathrm{d})$, which was used as an indigestible marker to estimate total-tract apparent digestibility (Schneider and Flatt, 1975). During the last $5 \mathrm{~d}$, TMR, orts, and fecal samples were collected twice daily after the morning and afternoon milkings. Samples of feces were composited for the 5-d collection period for individual cows and dried in a forced-air oven at $60^{\circ} \mathrm{C}$ for $72 \mathrm{~h}$.

\section{Laboratory Analysis}

Dried samples were ground to pass the 1-mm screen of a Wiley mill (A. H. Thomas, Philadelphia, PA) and analyzed for DM, ash, and ether extract according to AOAC (1990) procedures. Concentrations of NDF and ADF were measured in an Ankom 200 Fiber Analyzer (Ankom Technologies, Macedon, NY) using methods of Van Soest et al. (1991) for NDF and AOAC (1990) for ADF. Heat-stable $\alpha$-amylase was used in the NDF assay, and the results are presented exclusive of residual ash. Nitrogen was determined by rapid combustion using a Macro elemental $\mathrm{N}$ analyzer (Vario MAX CN, model no. 25.00-5003; Elementar, Hanau, Germany), and $\mathrm{CP}$ was calculated as $\mathrm{N} \times 6.25$. Fecal samples were also analyzed for chromium by atomic absorption spectrophotometry (Williams et al., 1962). Neutral detergent solubles were computed as 100 - ash - NDF. Nonfiber carbohydrates were calculated as $\mathrm{NFC}=100$ - CP - NDF - ether extract - ash.

Silage extracts were prepared by mixing $25 \mathrm{~g}$ of thawed silage with $225 \mathrm{~mL}$ of distilled water in a stomacher for $3 \mathrm{~min}$. The solution was filtered through 2 layers of cheesecloth, and the $\mathrm{pH}$ was measured using an electrode (Corning model 12, Corning Scientific Instruments, Medfield, MA). Afterward, an aliquot of 2 $\mathrm{mL}$ of silage extract was centrifuged at $2,000 \times g$ for $15 \mathrm{~min}$ at $4^{\circ} \mathrm{C}$. The supernatant was filtered with a $0.22-\mu \mathrm{m}$ syringe filter and used to quantify lactic, acetic, propionic, and butyric acids by higHPLC (Merck Hitachi, Elite Lachrom HTA, Tokyo, Japan). A UV detector (Merck Hitachi L-2400) set at $210 \mathrm{~nm}$ and a Bio-Rad Aminex HPX-87H column (Bio-Rad Labora- tories, Hercules, CA) with a $0.015 M$ sulfuric acid mobile phase and a flow rate of $0.7 \mathrm{~mL} / \mathrm{min}$ at $45^{\circ} \mathrm{C}$ were used (Arriola et al., 2011). Ethanol and 1,2-propanediol were measured with an HPLC (Merck Hitachi) coupled to a refractive index detector (Merck Hitachi L-2490; Queiroz et al., 2013). Ammonia N was measured by distillation (AOAC, 1985).

\section{Statistical Analysis}

Data were analyzed using the GLIMMIX procedure of SAS version 9.3 (SAS/STAT, SAS Institute Inc., Cary, NC). Data collected during the pretreatment period were used for covariate adjustment during statistical analyses. Outcomes with repeated measurements within the same experimental unit were analyzed with models that included the effects of treatment (control and inoculated), parity (primiparous and multiparous), day of measurement (20 to 100), interactions of these terms, and the pretreatment covariate. Cow nested within treatment was used as the error term in all models, whereas autoregressive (AR) 1 was used as the covariance structure.

Outcomes that involved a single measurement for each experimental unit (digestibility coefficients) were analyzed with a model that included effects of treatment, parity, and the interaction between treatment and parity. Significance was declared at $P<0.05$, whereas tendencies to differences were declared at $P>$ 0.05 and $<0.10$.

\section{RESULTS}

The chemical composition of the experimental silages is shown in Table 1 . The MC silage had higher concentrations of lactic acid and ethanol and lower concentrations of ammonia and acetic and propionic acids than the control silage. No differences in aerobic stability were detected among silages. Concentrations of DM, $\mathrm{CP}, \mathrm{NDF}, \mathrm{ADF}$, ether extract, ash, NFC, and neutral detergent solubles (NDS) did not differ across silages, resulting in diets with similar composition (Table 2).

Dry matter intake, milk fat concentration, milk protein yield, SCC, and feed efficiency (milk/DMI or FCM/DMI) did not differ among treatments (Table 3). However, cows fed MC produced more milk, FCM, milk fat, and lactose and their milk contained a lower concentration of protein and a greater concentration of lactose. The milk lactose concentration response tended to vary with time (treatment $\times$ day; $P=0.07$ ), but other treatment responses were unaffected by time. Parity influenced all performance responses except milk fat concentration, MUN, and SCC. Multiparous cows 
Table 1. Chemical composition $( \pm \mathrm{SD})$ of inoculated $(\mathrm{MC})$ and untreated $(\mathrm{CON})$ corn silage (\% of DM unless otherwise stated; $\mathrm{n}=5$ )

\begin{tabular}{lcc}
\hline & \multicolumn{2}{c}{ Treatment } \\
\cline { 2 - 3 } Item & CON & MC \\
\hline DM, \% as fed & $34.7 \pm 4.70$ & $33.9 \pm 1.13$ \\
CP & $8.34 \pm 0.29$ & $8.25 \pm 0.17$ \\
NDF & $43.1 \pm 4.07$ & $43.9 \pm 1.17$ \\
ADF & $25.7 \pm 2.63$ & $26.5 \pm 1.47$ \\
Hemicellulose & $17.4 \pm 1.75$ & $18.5 \pm 1.01$ \\
Ether extract & $3.15 \pm 0.11$ & $3.31 \pm 0.16$ \\
Ash & $3.40 \pm 0.25$ & $3.20 \pm 0.14$ \\
NFC & $42.0 \pm 4.14$ & $41.3 \pm 3.97$ \\
NDS & $53.5 \pm 3.86$ & $52.9 \pm 1.12$ \\
pH & $3.72 \pm 0.10$ & $3.70 \pm 0.12$ \\
Lactic acid & $3.83 \pm 1.12$ & $4.48 \pm 1.00$ \\
Acetic acid & $2.34 \pm 0.29$ & $1.68 \pm 0.65$ \\
Propionic acid & $0.37 \pm 0.32$ & $0.10 \pm 0.21$ \\
Butyric acid & $0.01 \pm 0.00$ & $0.01 \pm 0.00$ \\
Ethanol & $0.57 \pm 0.54$ & $2.14 \pm 0.82$ \\
1,2-Propanediol & $0.90 \pm 0.24$ & $0.39 \pm 0.32$ \\
Ammonia N, \% total N & $9.11 \pm 1.38$ & $7.82 \pm 1.03$ \\
Total acids & $6.54 \pm 1.12$ & $6.26 \pm 0.51$ \\
Lactic acid:acetic acid & $1.66 \pm 0.52$ & $3.20 \pm 1.72$ \\
Lactic acid, \% of total acids & $57.6 \pm 10.2$ & $71.2 \pm 13.6$ \\
Aerobic stability, h & $73.0 \pm 66.7$ & $76.7 \pm 61.4$
\end{tabular}

${ }^{1}$ Hemicellulose $=$ NDF - ADF.

${ }^{2} \mathrm{NFC}=100-\mathrm{CP}-\mathrm{NDF}-$ ether extract - ash.

${ }^{3}$ Neutral detergent solubles $=100-$ ash - NDF .

had higher yields of milk and milk solids but lower concentrations of milk protein and lactose. However, parity interacted only with treatment effects on DMI, milk protein concentration, and feed efficiency. There was a tendency $(P=0.12)$ for higher DMI by multiparous cows fed MC compared with the CON (26.2 vs. $25.6 \mathrm{~kg} / \mathrm{d}$ ), whereas there was no difference in DMI among primiparous cows $(\sim 20.5 \mathrm{~kg} / \mathrm{d})$. Milk protein was higher $(P<0.01)$ in primiparous cows $(2.95 \%)$
Table 2. Ingredients and chemical compositions $( \pm \mathrm{SD})$ of rations containing inoculated $(\mathrm{MC})$ and untreated $(\mathrm{CON})$ corn silage $(\mathrm{n}=5)$

\begin{tabular}{lcc}
\hline & \multicolumn{2}{c}{ Treatment } \\
\cline { 2 - 3 } Item & CON & MC \\
\hline Ingredient composition, \% of TMR & \multicolumn{2}{c}{} \\
Untreated corn silage & 35.1 & - \\
Inoculated corn silage & 10.9 & 10.9 \\
Alfalfa hay & 3.6 & 3.6 \\
Whole cottonseed & 18.2 & 18.2 \\
Corn grain, ground & 10.0 & 10.0 \\
Soybean hulls & 5.5 & 5.5 \\
Citrus pulp & 8.7 & 8.7 \\
Soybean meal & 4.0 & 4.0 \\
AminoPlus & 4.0 & 4.0 \\
Mineral and vitamin mix ${ }^{2}$ & & \\
Chemical composition, \% of DM & & \\
unless stated & $58.4 \pm 0.03$ & $58.4 \pm 0.04$ \\
DM, \% as fed & $16.7 \pm 0.61$ & $17.0 \pm 0.63$ \\
CP & $34.7 \pm 2.09$ & $35.9 \pm 1.11$ \\
NDF & $22.9 \pm 1.04$ & $23.9 \pm 0.91$ \\
ADF & $3.89 \pm 0.58$ & $3.93 \pm 0.73$ \\
Ether extract & $6.89 \pm 0.30$ & $7.15 \pm 0.23$ \\
Ash & $37.8 \pm 2.25$ & $36.0 \pm 1.98$ \\
NFC ${ }^{3}$ & $58.4 \pm 1.98$ & $57.0 \pm 1.06$ \\
NDS &
\end{tabular}

${ }^{1}$ AminoPlus: high-bypass soybean meal product (AGP, Omaha, NE). ${ }^{2}$ Composition (DM basis): $6.35 \% \mathrm{Ca}, 1.25 \% \mathrm{P}, 3.99 \% \mathrm{Mg}, 0.07 \% \mathrm{~K}$, $0.84 \% \mathrm{~S}, 12.54 \% \mathrm{Na}, 3.08 \% \mathrm{Cl}, 945 \mathrm{mg} / \mathrm{kg}$ of $\mathrm{Zn}, 854 \mathrm{mg} / \mathrm{kg}$ of $\mathrm{Mn}$, $1,660 \mathrm{mg} / \mathrm{kg}$ of Fe, $251 \mathrm{mg} / \mathrm{kg}$ of Cu, $19 \mathrm{mg} / \mathrm{kg}$ of I, $10 \mathrm{mg} / \mathrm{kg}$ of Se, $25 \mathrm{mg} / \mathrm{kg}$ of $\mathrm{Co}, 23,591 \mathrm{IU} / \mathrm{kg}$ of vitamin A, 8,493 IU/ $\mathrm{kg}$ of vitamin $\mathrm{D}_{3}, 236 \mathrm{IU} / \mathrm{kg}$ of vitamin $\mathrm{E}$, and $480 \mathrm{mg} / \mathrm{kg}$ of monensin.

${ }^{3} \mathrm{NFC}=100-\mathrm{CP}-\mathrm{NDF}-$ ether extract - ash.

${ }^{4}$ Neutral detergent solubles $=100-$ ash - NDF.

than in multiparous cows $(2.91 \%)$ fed CON, but there was no parity-related difference among cows fed MC $(\sim 2.83 \%)$. Treating silage with $\mathrm{MC}$ tended $(P=0.10)$ to improve feed efficiency (FCM/DMI) of primiparous cows (1.83 vs. 1.74$)$ but not multiparous cows $(\sim 1.63)$.

Table 3. Effect of treatment of corn silage without $(\mathrm{CON})$ or with $(\mathrm{MC})$ an inoculant on the performance of dairy cows

\begin{tabular}{|c|c|c|c|c|c|c|c|c|c|}
\hline \multirow[b]{2}{*}{ Item } & \multicolumn{2}{|c|}{ Treatment } & \multirow[b]{2}{*}{ SEM } & \multicolumn{6}{|c|}{$P$-value ${ }^{1}$} \\
\hline & $\mathrm{CON}$ & $\mathrm{MC}$ & & $\mathrm{T}$ & $\mathrm{D}$ & $\mathrm{T} \times \mathrm{D}$ & $\mathrm{P}$ & $\mathrm{T} \times \mathrm{P}$ & $\mathrm{T} \times \mathrm{P} \times \mathrm{D}$ \\
\hline DMI, $\mathrm{kg} / \mathrm{d}$ & 23.1 & 23.2 & 0.13 & 0.51 & $<0.01$ & 0.99 & $<0.01$ & 0.02 & 0.87 \\
\hline Milk yield, $\mathrm{kg} / \mathrm{d}$ & 37.7 & 38.5 & 0.23 & 0.02 & $<0.01$ & 0.88 & $<0.01$ & 0.37 & 0.61 \\
\hline $3.5 \% \mathrm{FCM}, \mathrm{kg} / \mathrm{d}$ & 37.6 & 38.4 & 0.23 & $<0.01$ & $<0.01$ & 0.95 & $<0.01$ & 0.68 & 0.67 \\
\hline Milk fat, $\%$ & 3.47 & 3.44 & 0.011 & 0.14 & 0.36 & 0.36 & 0.14 & 0.27 & 0.99 \\
\hline Milk fat, $\mathrm{kg} / \mathrm{d}$ & 1.30 & 1.33 & 0.008 & 0.03 & $<0.01$ & 0.92 & $<0.01$ & 0.56 & 0.80 \\
\hline Milk protein, \% & 2.93 & 2.83 & 0.005 & $<0.01$ & $<0.01$ & 0.47 & $<0.01$ & 0.01 & 0.63 \\
\hline Milk protein, $\mathrm{kg} / \mathrm{d}$ & 1.10 & 1.09 & 0.007 & 0.19 & $<0.01$ & 0.76 & $<0.01$ & 0.78 & 0.44 \\
\hline Milk lactose, $\%$ & 4.86 & 4.93 & 0.005 & $<0.01$ & 0.17 & 0.07 & $<0.01$ & 0.12 & 0.76 \\
\hline Milk lactose, $\mathrm{kg} / \mathrm{d}$ & 1.83 & 1.92 & 0.012 & $<0.01$ & $<0.01$ & 0.96 & $<0.01$ & 0.76 & 0.63 \\
\hline MUN, mg/dL & 12.9 & 13.1 & 0.25 & 0.52 & 0.06 & 0.56 & 0.78 & 0.46 & 0.45 \\
\hline $\mathrm{SCC}, \times 1,000$ cells $/ \mathrm{mL}$ & 215 & 237 & - & - & - & - & - & - & - \\
\hline $\log _{10} \mathrm{SCC}$ & 1.79 & 1.85 & 0.087 & 0.62 & 0.02 & 0.68 & 0.66 & 0.99 & 0.46 \\
\hline Milk/DMI & 1.70 & 1.73 & 0.020 & 0.29 & $<0.01$ & 0.91 & $<0.01$ & 0.06 & 0.72 \\
\hline $\mathrm{FCM} / \mathrm{DMI}$ & 1.69 & 1.72 & 0.019 & 0.25 & $<0.01$ & 0.97 & $<0.01$ & 0.03 & 0.74 \\
\hline
\end{tabular}

${ }^{1} \mathrm{~T}=$ effect of treatment; $\mathrm{D}=$ effect of day; $\mathrm{P}=$ effect of parity. 
Table 4. Effect of treatment of corn silage with $(\mathrm{MC})$ or without $(\mathrm{CON})$ an inoculant on the intake and digestibility of a corn silage-based TMR

\begin{tabular}{|c|c|c|c|c|c|c|}
\hline \multirow[b]{2}{*}{ Item } & \multicolumn{2}{|c|}{ Treatment } & \multirow[b]{2}{*}{ SEM } & \multicolumn{3}{|c|}{$P$-value ${ }^{1}$} \\
\hline & $\mathrm{CON}$ & $\mathrm{MC}$ & & $\mathrm{T}$ & $\mathrm{P}$ & $\mathrm{T} \times \mathrm{P}$ \\
\hline \multicolumn{7}{|l|}{ Digestibility, \% } \\
\hline $\mathrm{DM}$ & 68.8 & 70.8 & 0.60 & 0.02 & 0.97 & 0.73 \\
\hline NDF & 55.2 & 57.4 & 0.93 & 0.09 & 0.72 & 0.91 \\
\hline $\mathrm{NDS}^{2}$ & 85.4 & 88.6 & 0.49 & $<0.01$ & 0.64 & 0.87 \\
\hline Diet $\mathrm{NE}_{\mathrm{L}},{ }^{3} \mathrm{Mcal} / \mathrm{kg}$ of $\mathrm{DM}$ & 1.65 & 1.71 & 0.019 & 0.02 & 0.98 & 0.70 \\
\hline \multicolumn{7}{|l|}{ BW measures } \\
\hline Initial BW, kg & 563 & 565 & 10.5 & 0.89 & $<0.01$ & 0.66 \\
\hline Final BW, kg & 604 & 603 & 8.9 & 0.98 & $<0.01$ & 0.23 \\
\hline BW change, $\mathrm{kg} / \mathrm{d}$ & 0.466 & 0.467 & 0.043 & 0.98 & 0.06 & 0.05 \\
\hline \multicolumn{7}{|l|}{ Energy partitioning, Mcal/d } \\
\hline $\mathrm{NE}_{\mathrm{J}}$ intake & 38.1 & 39.6 & 0.76 & 0.16 & $<0.01$ & 0.44 \\
\hline $\mathrm{NE}_{\mathrm{L}}$ maintenance ${ }^{4}$ & 9.48 & 9.51 & 0.12 & 0.88 & $<0.01$ & 0.37 \\
\hline $\mathrm{NE}_{\mathrm{L}}$ lactation $^{4}$ & 25.3 & 25.9 & 0.53 & 0.39 & $<0.01$ & 0.88 \\
\hline $\mathrm{NE}_{\mathrm{L}}$ balance ${ }^{5}$ & 3.32 & 4.30 & 0.69 & 0.31 & 0.43 & 0.47 \\
\hline
\end{tabular}

Cows fed the MC diet had greater apparent digestibility of DM and NDS and tended $(P=0.09)$ to have greater NDF digestibility. Consequently, the MC diet had higher calculated concentration of $\mathrm{NE}_{\mathrm{L}}$ (Table 4). Primiparous cows had lower initial and final BW as well as lower $\mathrm{NE}_{\mathrm{L}}$ intake and $\mathrm{NE}_{\mathrm{L}}$ requirements for maintenance and lactation than multiparous cows. Nonetheless, parity interacted with the BW change response $(P=0.06)$ because multiparous cows had lower BW change than primiparous cows fed the CON diet ( 0.348 vs. $0.583 \mathrm{~kg} / \mathrm{d})$, but no parity-related difference was found among cows fed the MC $\operatorname{diet}(\sim 0.467 \mathrm{~kg} / \mathrm{d})$.

\section{DISCUSSION}

Homolactic bacteria have been widely used as inoculants to improve silage fermentation and thereby potentially enhance animal performance by improving nutrient intake and utilization (Weinberg et al., 2004). As expected, in the current study the MC silage underwent more homofermentation than the CON silage as shown by its relatively greater lactic acid concentration and lower concentrations of acetic and propionic acids and ammonia.

Compared with those from cold climates, which often undergo a homolactic fermentation, corn silages produced in warm climates such as in Florida typically undergo a more heterolactic fermentation (Kim and Adesogan, 2006; Wang and Nishino, 2013; Weiss et al., 2016; Zhou et al., 2016). The reason for this occurrence is unclear, but it may be due to a higher population of heterofermentative epiphytic bacteria in warmer climates. In this study, the CON silage had a natural, more heterolactic fermentation as evidenced by the low lactic acid:acetic acid ratio (1.66 vs. 3.20) as in other studies cited above.

Inoculation of corn silage with a mixture of homolactic bacteria (MC) including Lc. lactis, Lb. plantarum, and E. faecium increased the concentration of lactic acid by $17 \%$ and decreased the formation of products derived from heterofermentative pathways, such as acetic and propionic acids and ammonia. Although alcohols are not major products of homolactic pathways, the MC silage had more ethanol, probably because it had relatively fewer antifungal compounds such as acetic and propionic acids that inhibit ethanol-producing yeasts (Woolford, 1975; Moon, 1983).

No differences were detected in aerobic stability among silages, likely because of the relatively high feed-out rate $(2 \mathrm{~m} / \mathrm{wk})$. Although high temperatures are often more conducive for the growth of spoilage organisms (Ashbell et al., 2002; Koc et al., 2009), the high feed-out rate and the levels of naturally produced antifungal fermentation products (e.g., $1.68 \%$ of acetic acid) may have been sufficient to curtail aerobic deterioration for the duration of the aerobic phase in the current study.

Cows fed MC produced more milk, FCM, milk fat, and lactose, probably because of the higher DM digestibility of diet containing the MC silage. Moreover, the increased supply of lactic acid by MC silage presumably enhanced the net portal flux of glucose precursors 
(e.g., propionate, lactate) and milk lactose synthesis (Aschenbach et al., 2010). The greater secretion of milk lactose may have induced higher milk yield to maintain the osmotic gradient between milk and plasma (Peaker, 1975).

The higher milk fat yield was likely due to the higher milk production by cows fed MC silage. In contrast, the lower concentration of milk protein in cows fed $\mathrm{MC}$ was probably due to dilution because the yield of milk protein was similar across treatments. Milk protein yield accounts for most $(>70 \%)$ of the MP requirement of lactating dairy cows (NRC, 2001), and milk protein yield is positively correlated with intestinal supply of MP $\left(\mathrm{R}^{2}=0.98\right.$; Huhtanen et al., 2008) because ruminal microbial protein is the main source of MP (NRC, 2001). Silages treated with LAB have had greater microbial biomass yield in vitro in a previous study (Contreras-Govea et al., 2011). However, the similarity in milk protein yield by cows fed both treatments in the current study suggests that the improvement in milk yield in cows fed $\mathrm{MC}$ was not due to higher microbial protein synthesis in the rumen.

As mentioned earlier, the MC diet had greater apparent digestibility of DM and NDS and tended to have greater NDF digestibility. In fact, digestibility of both NDF (i.e., cell wall) and NDS (i.e., cellular contents) was enhanced by the same magnitude $(\sim 4 \%)$, indicating an overall improvement in total-tract digestibility, possibly induced by better rumen function. Adesogan et al. (2009) reported the same level of improvement in DM digestibility (4.3\%) when silages were inoculated with homofermentative or facultative heterofermentative inoculants. Interestingly, $\mathrm{MC}$ tended to improve feed efficiency (FCM/DMI) of primiparous cows by $5 \%$ due to a numerical decrease in DMI $(-2 \%)$ associated with a numerical increase in FCM yield $(+2 \%)$. In multiparous cows, the higher FCM yield was accompanied by higher DMI such that feed efficiency was not changed. Differences in feed efficiency among primiparous and multiparous cows were probably caused by the level of feed intake (multiparous $>$ primiparous), which is negatively associated with the dietary energy value. Diets with higher digestibility at lower feeding level exhibit a greater rate of depression in digestibility with level of feeding (NRC, 2001).

Although the exact mechanism of action is unknown, previous studies have also reported that inoculants increased DM digestibility in vitro (Weinberg et al., 2007; Cao et al., 2011) and in vivo (Kung and Muck, 1997; Ando et al., 2006). This may be due to the hydrolytic effect of enzymes produced by LAB or added to LAB. Diet supplementation with lactic acid has been associated with higher rumen $\mathrm{pH}$ (Jaakkola and Huhtanen,
1989; Daniel et al., 2013), which may contribute to the higher diet digestibility by improving conditions for cellulolytic bacteria. The higher digestibility of the diet containing the MC silage might have increased the net portal flux of nutrients to support the increase of FCM $(+0.8 \mathrm{~kg} / \mathrm{d})$.

In addition to higher apparent digestibility, previous reports also indicated that homofermentative LAB treatment reduced methane production during ruminal fermentation of silages (Muck et al., 2007; Cao et al., 2010). Recently, Kamke et al. (2016) reported higher bacterial abundance and gene expression related to lactate metabolism (e.g., acrylate pathway) in the rumen of low-methane-emitting sheep compared with their high-methane-emitting counterparts. Additionally, genes encoding the acrylate pathway were reported to be enriched in the ruminal microbiome of dairy cows with higher feed efficiency, and many of these genes were annotated as being from Megasphaera elsdenii, a utilizer of lactate (Shabat et al., 2016). In the current trial, the potential beneficial effect of the higher content of lactic acid on methane formation (electron acceptor; Counotte and Prins, 1978) might have been countered, at least partially, by the higher content of ethanol (electron donor; Czerkawski and Breckenridge, 1972) in the MC silage. Although the control silage contained more 1,2-propanediol than the MC silage, ruminal 1,2-propanediol is partially metabolized to propanal, which in turn is converted to equal amounts of propionate (electron donor) and 1-propanol (electron acceptor; Kristensen and Raun, 2007). Therefore, only minor effects of silage 1,2-propanediol would be expected on ruminal methanogenesis.

The results of this study validate the hypothesis that inoculant treatment would increase the performance of dairy cows. They also support the results of the recent meta-analysis that showed that homofermentative or facultative heterofermentative LAB treatment increased milk yield $(+0.37 \mathrm{~kg} / \mathrm{d})$ by dairy cows (Oliveira et al., 2017). Most studies in the meta-analysis involved only $L b$. plantarum, whereas this study involved $L b$. plantarum, E. faecium, and Lc. lactis. More research is warranted to confirm whether the increase in milk yield observed in the current study was due to Lb. plantarum alone or the combination of homolactic bacteria.

\section{CONCLUSIONS}

Inoculation of corn silage with a homofermentative inoculant made the fermentation more homofermentative as shown by higher concentrations of lactic acid and lower concentrations of propionic and acetic acid. Relative to the control silage, the inoculant-treated si- 
lage increased DM, NDF, and NDS digestion and milk yield, FCM yield, and milk fat yield when it was fed as part of a TMR to dairy cows in early lactation.

\section{ACKNOWLEDGMENTS}

The authors thank the staff of the University of Florida Dairy Unit (Gainesville) for assistance with the study and gratefully acknowledge financial support from Chr. Hansen A/S (Hørsholm, Denmark).

\section{REFERENCES}

Adesogan, A. T., O. C. M. Queiroz, and M. F. Queiroz. 2009. Homolactic inoculants for improving silage nutrient digestibility. In Proc. 2009 Tri-State Dairy Nutrition Pre-Conf. Symp., Setting the next standard with Generation 2.0 microbials. April 21, 2009. Fort Wayne, IN.

Ando, S., M. Ishida, S. Oshio, and O. Tanaka. 2006. Effects of isolated and commercial lactic acid bacteria on the silage quality, digestibility, voluntary intake and ruminal fluid characteristics. AsianAustralas. J. Anim. Sci. 19:386-389.

AOAC. 1985. Official Methods of Analysis. 14th ed. Association of Official Analytical Chemists, Washington, DC.

AOAC. 1990. Official Methods of Analysis. 15th ed. Association of Official Analytical Chemists, Arlington, VA.

Arriola, K. G., S. C. Kim, and A. T. Adesogan. 2011. Effect of applying inoculants with heterolactic or homolactic and heterolactic bacteria on the fermentation and quality of corn silage. J. Dairy Sci. 94:1511-1516.

Aschenbach, J. R., N. B. Kristensen, S. S. Donkin, H. M. Hammon, and G. B. Penner. 2010. Gluconeogenesis in dairy cows: The secret of making sweet milk from sour dough. IUBMB Life 62:869-877.

Ashbell, G., Z. G. Weinberg, Y. Hen, and I. Filya. 2002. The effects of temperature on the aerobic stability of wheat and corn silages. J. Ind. Microbiol. Biotechnol. 28:261-263.

Basso, F. C., A. T. Adesogan, E. C. Lara, C. H. S. Rabelo, T. T. Berchielli, I. A. M. A. Teixeira, G. R. Siqueira, and R. A. Reis. 2014. Effects of feeding corn silage inoculated with microbial additives on the ruminal fermentation, microbial protein yield and growth performance of lambs. J. Anim. Sci. 92:5640-5650.

Cao, Y., Y. Cai, T. Takahashi, N. Yoshida, M. Tohno, R. Uegaki, K. Nonaka, and F. Terada. 2011. Effect of lactic acid bacteria inoculant and beet pulp addition on fermentation characteristics and in vitro ruminal digestion of vegetable residue silage. J. Dairy Sci. 94:3902-3912.

Cao, Y., T. Takahashi, K.-I. Horiguchi, and N. Yoshida. 2010. Effect of adding lactic acid bacteria and molasses on fermentation quality and in vitro ruminal digestion of total mixed ration silage prepared with whole crop rice. Grassl. Sci. 56:19-25.

Contreras-Govea, F., R. Muck, D. Mertens, and P. Weimer. 2011. Microbial inoculant effects on silage and in vitro ruminal fermentation, and microbial biomass estimation for alfalfa, BMR corn, and corn silages. Anim. Feed Sci. Technol. 163:2-10.

Counotte, G. H. M., and R. A. Prins. 1978. Regulation of rumen lactate metabolism and the role of lactic acid in nutritional disorders of ruminants. Vet. Sci. Commun. 2:277-303.

Czerkawski, J. W., and G. Breckenridge. 1972. Fermentation of various glycolytic intermediates and other compounds by rumen microorganisms, with particular reference to methane production. Br. J. Nutr. 27:131-146.

Daniel, J. L. P., R. C. Amaral, R. S. Goulart, M. Zopolatto, V. P. Santos, S. G. Toledo Filho, E. H. Cabezas-Garcia, J. R. Lima, M. C. Santos, and L. G. Nussio. 2013. Short-term effects of silage volatile compounds on feed intake and digestion of beef cattle. J. Anim. Sci. 91:2321-2331.
Han, H., Y. Ogata, Y. Yamamoto, S. Nagao, and N. Nishino. 2014. Identification of lactic acid bacteria in the rumen and feces of dairy cows fed total mixed ration silage to assess the survival of silage bacteria in the gut. J. Dairy Sci. 97:5754-5762.

Huhtanen, P., M. Rinne, and J. Nousiainen. 2008. Effects of silage soluble N components on metabolizable protein concentration: A meta-analysis of dairy cow production experiments. J. Dairy Sci. 91:1150-1158.

Jaakkola, S., and P. Huhtanen. 1989. The effect of lactic acid on the microbial protein synthesis in the rumen of cattle. Am. J. Appl. Sci. 2:398-399.

Kamke, J., S. Kittelmann, P. Soni, Y. Li, M. Tavendale, S. Ganesh, P. H. Janssen, W. Shi, J. Froula, E. M. Rubin, and G. T. Attwood. 2016. Rumen metagenome and metatranscriptome analyses of low methane yield sheep reveals a Sharpea-enriched microbiome characterised by lactic acid formation and utilisation. Microbiome 4:56. https://doi.org/10.1186/s40168-016-0201-2.

Kim, S. C., and A. T. Adesogan. 2006. Influence of ensiling temperature, simulated rainfall, and delayed sealing on fermentation characteristics and aerobic stability of corn silage. J. Dairy Sci. 89:3122-3132.

Koc, F., L. Coskuntuna, M. L. Ozduven, A. Coskuntuna, and H. E Samli. 2009. The effects of temperature on the silage microbiology and aerobic stability of corn and vetch-grain silages. Acta Agric. Scand. A 59:239-246.

Kristensen, N. B., and B. M. L. Raun. 2007. Ruminal and intermediary metabolism of propylene glycol in lactating Holstein cows. J. Dairy Sci. 90:4707-4717.

Kung, L., Jr., and R. E. Muck. 1997. Animal response to silage additives. Pages 200-210 in Proc. Silage: Field to Feedbunk North American Conference. NRAES-99. Northeast Regional Agricultural Engineering Service, Ithaca, NY.

Kung, L., Jr., M. R. Stokes, and C. J. Lin. 2003. Silage additives. Pages 305-360 in Silage Science and Technology. D. R. Buxton, R. E. Muck, and J. H. Harrison, ed. American Society of Agronomy Inc., Crop Science Society of America Inc., and Soil Science Society of America Inc., Madison, WI.

Lindgren, S., K. Pettersson, A. Johnsson, P. Lingvall, and A. Kaspersson. 1985. Silage inoculation. Selected strains, temperature, wilting and practical application. Swed. J. Agric. Res. 15:9-18.

McDonald, P., N. Henderson, and S. Heron. 1991. The Biochemistry of Silage. 2nd ed. Chalcombe, Marlow, UK.

Moon, N. J. 1983. Inhibition of the growth of acid tolerant yeasts by acetate, lactate and propionate and their synergistic mixtures. J. Appl. Bacteriol. 55:453-460.

Muck, R. E., I. Filya, and F. E. Contreras-Govea. 2007. Inoculant effects on alfalfa silage: In vitro gas and volatile fatty acid production. J. Dairy Sci. 90:5115-5125.

NRC. 2001. Nutrient Requirements of Dairy Cattle. 7th rev. ed. National Academy Press, Washington, DC.

Oliveira, A. S., Z. G. Weinberg, I. M. Ogunade, A. A. P. Cervantes, K. G. Arriola, Y. Jiang, D. Kim, X. Li, M. C. M. Gonçalves, D. Vyas, and A. T. Adesogan. 2017. Meta-analysis of effects of homofermentative and facultative heterofermentative lactic acid bacteria inoculation on silage fermentation and aerobic stability and the performance of dairy cows. J. Dairy Sci. 100:4587-4603. https:// doi.org/10.3168/jds.2016-11815.

Peaker, M. 1975. Recent advances in the study of monovalent ion movements across the mammary epithelium: Relation to onset lactation. J. Dairy Sci. 58:1042-1047.

Queiroz, O. C. M., K. G. Arriola, J. L. P. Daniel, and A. T. Adesogan 2013. Effects of 8 chemical and bacterial additives on the quality of corn silage. J. Dairy Sci. 96:5836-5843.

Schneider, B. H., and W. P. Flatt. 1975. The indicator method. Page 168 in The Evaluation of Feeds Through Digestibility Experiments. Univ. Georgia Press, Athens.

Shabat, S. K. B., G. Sasson, A. Doron-Faigenboim, T. Durman, S. Yaacoby, M. E. Berg Miller, B. A. White, N. Shterzer, and I. Mizrahi. 2016. Specific microbiome-dependent mechanisms underlie the energy harvest efficiency of ruminants. ISME J. 10:2958-2972. 
Tyrrell, H. F., and J. T. Reid. 1965. Prediction of the energy value of cow's milk. J. Dairy Sci. 48:1215-1223.

Van Soest, P. J., J. B. Robertson, and B. A. Lewis. 1991. Methods for dietary fiber, neutral detergent fiber, and nonstarch polysaccharides in relation to animal nutrition. J. Dairy Sci. 74:3583-3597.

Wang, C., and N. Nishino. 2013. Effects of storage temperature and ensiling period on fermentation products, aerobic stability and microbial communities of total mixed ration silage. J. Appl. Microbiol. 114:1687-1695.

Weinberg, Z. G., R. E. Muck, and P. J. Weimer. 2003. The survival of silage inoculant lactic acid bacteria in rumen fluid. J. Appl. Microbiol. 94:1066-1071.

Weinberg, Z. G., R. E. Muck, P. J. Weimer, Y. Chen, and M. Gamburg. 2004. Lactic acid bacteria used in inoculants for silage as probiotics for ruminants. Appl. Biochem. Biotechnol. 118:1-9.

Weinberg, Z. G., O. Shatz, Y. Chen, E. Yosef, M. Nikbahat, D. BenGhedalia, and J. Miron. 2007. Effect of lactic acid bacteria inocu- lants on in vitro digestibility of wheat and corn silages. J. Dairy Sci. 90:4754-4762.

Weiss, K., B. Kroschewski, and H. Auerbach. 2016. Effects of air exposure, temperature, and additives on fermentation characteristics, yeast count, aerobic stability, and volatile organic compounds in corn silage. J. Dairy Sci. 99:8053-8069.

Williams, C. H., D. J. David, and O. Iismaa. 1962. The determination of chromic oxide in feces samples by atomic absorption spectrophotometry. J. Agric. Sci. 59:381-385.

Woolford, M. K. 1975. Microbiological screening of straight chain fatty acids $(\mathrm{C} 1-\mathrm{C} 12)$ as potential silage additives. J. Sci. Food Agric. 26:219-228.

Zhou, Y., P. Drouin, and C. Lafreniere. 2016. Effect of temperature $\left(5-25^{\circ} \mathrm{C}\right)$ on epiphytic lactic acid bacteria populations and fermentation of whole-plant corn silage. J. Appl. Microbiol. 121:657-671. 